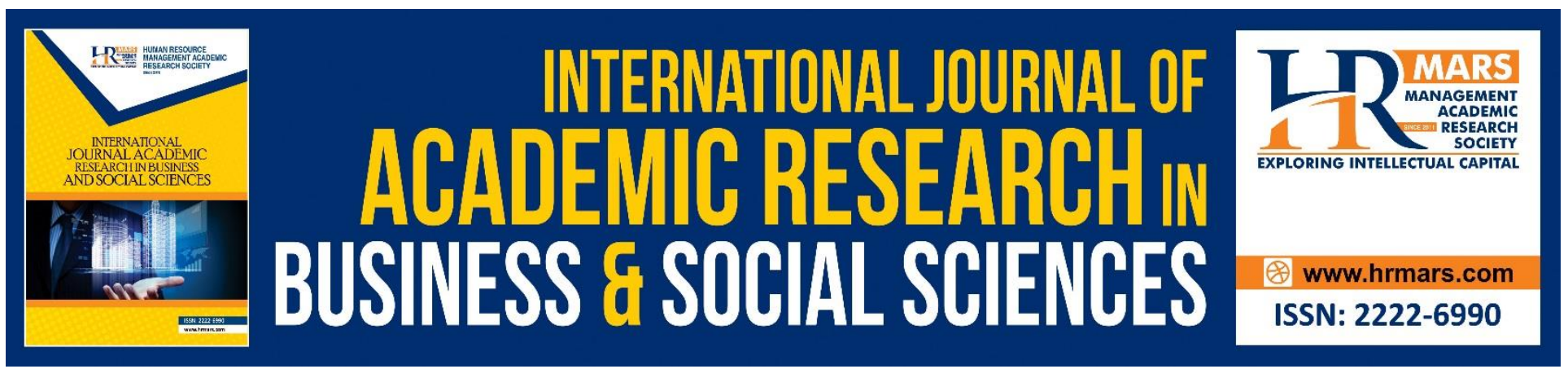

\title{
British Policy on the Palestinian Question in the Middle East Peace Negotiations: From Conservative to Labour (1970- 1979)
}

Muhamad Hasrul Zakariah

To Link this Article: http://dx.doi.org/10.6007/IJARBSS/v8-i11/4985

DOI: 10.6007/IJARBSS/v8-i11/4985

Received: 08 Oct 2018, Revised: 13 Nov 2018, Accepted: 26 Nov 2018

Published Online: 03 Dec 2018

In-Text Citation: (Zakariah, 2018)

To Cite this Article: Zakariah, M. H. (2018). British Policy on the Palestinian Question in the Middle East Peace Negotiations: From Conservative to Labour (1970-1979). International Journal of Academic Research in Business and Social Sciences, 8(11), 1069-1092.

Copyright: (c) 2018 The Author(s)

Published by Human Resource Management Academic Research Society (www.hrmars.com) This article is published under the Creative Commons Attribution (CC BY 4.0) license. Anyone may reproduce, distribute, translate and create derivative works of this article (for both commercial and non-commercial purposes), subject to full attribution to the original publication and authors. The full terms of this license may be seen at: $\underline{\text { http://creativecommons.org/licences/by/4.0/legalcode }}$

Vol. 8, No. 11, 2018, Pg. 1069 - 1092

http://hrmars.com/index.php/pages/detail/IJARBSS JOURNAL HOMEPAGE

Full Terms \& Conditions of access and use can be found at http://hrmars.com/index.php/pages/detail/publication-ethics 


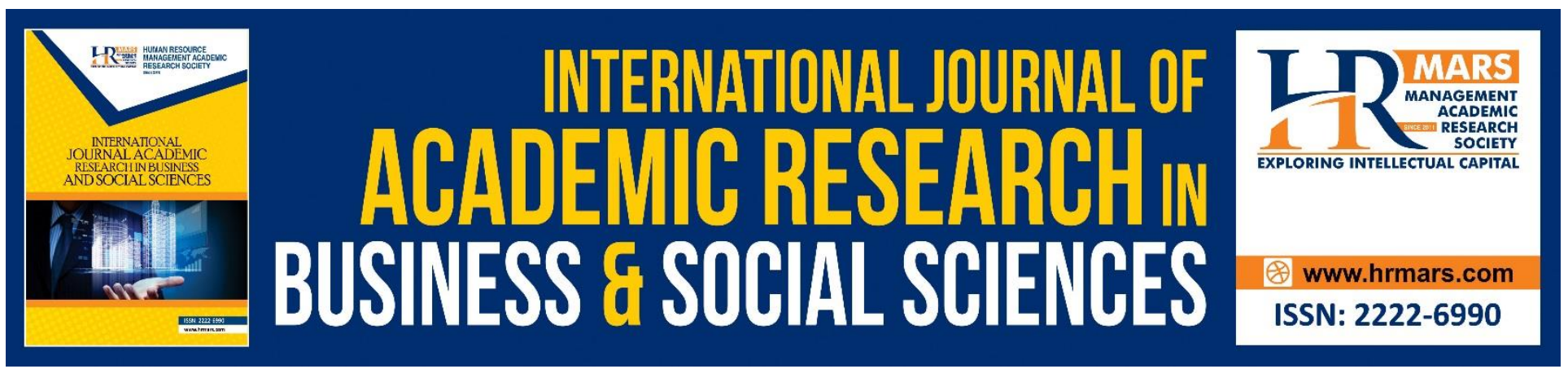

\title{
British Policy on the Palestinian Question in the Middle East Peace Negotiations: From Conservative to Labour (1970-1979)
}

\author{
Muhamad Hasrul Zakariah \\ School of Humanities, Universiti Sains Malaysia, Penang Malaysia \\ Email: hasrul74@usm.my
}

\section{Abstract}

From 1970 to 1979, the Middle East peace negotiations were led and dominated by the United States. Thus, less scholarly attention has therefore been given to the British policy on the Middle East peace settlement through this period, particularly regarding the issue of the Palestinian question. The British government role and participation in the Arab Israeli settlement seemed inactive and marginal. However, a solution of the Palestinian question was consistently viewed by the British as the most important issue in a comprehensive plan that could lead to a just and durable peace in the Middle East. Although Britain did not involves directly with the US's peace negotiation, London has repeatedly declared her policy in the public, either unilaterally or jointly with her European Allies. By analysing archival records recently declassified in London, this paper examines the British policy and diplomacy towards the Palestinian question during the peace negotiations period from 1970 to 1979. In spite of a political change of the British government between Conservative and Labour, the finding of this study proven that Britain under both parties was remains consistent with her policy towards the Palestinian question.

Keywords: British, Middle East, Palestine, Policy, Peace negotiation

\section{Introduction}

After the Arab-Israeli October War of 1973, the Palestinian question was one of the crucial issues of the peace settlement agenda. Peace negotiations during the period 1970 to 1979 were led by the Americans, first by the Secretary of State, Dr. Henry Kissinger in his famous 'shuttle diplomacy' from 1973 to 1977 and then by President Jimmy Carter who orchestrated the Camp David Accords between President Anwar Sadat of Egypt and the Prime Minister of Israel, Menachem Begin. However, during this period, although not wholly abandoned, the Palestinian question was treated as a low priority issue. In the Rogers Plan of 1969 the Americans touched on the Palestinian question as 'refugee' problem which had to be dealt with between the Israelis and Jordan. During the Kissinger 
mission, the Palestinian question was excluded from engagement negotiations due to pro-Israeli pressure, domestically and internationally (Quandt, 1977.p.278). In fact, Dr. Kissinger only brokered bilateral peace agreements rather than tackling a comprehensive peace by including the Palestinians. Kissinger at first intended to deal with the issues between Jordan and Israel but the idea was abandoned after the Arab Rabat Summit in 1974 which unanimously endorsed the Palestinian Liberation Organisation (PLO) as the sole legitimate representative of the Palestinian people. This act meant that King Hussein of Jordan lost any political locus standi to represent the Palestinians in the peace negotiations. Nonetheless, Israeli intransigence and a refusal to hold direct talks with the PLO made the Palestinian issues more difficult if not impossible to solve. (Quandt, 1977, p. 286). According to researchers such as Dan Tschirgi, seeing Palestinian political activism as an unwanted radicalizing force in the Middle East, and unwilling to challenge Israel's fundamental abhorrence of the concept of Palestinian national identity, Washington had no desire to deal with the central element of ArabIsrael tensions. Indeed after King Hussein accepted the decree of Rabat Summit Conference, Washington's negative attitude towards Palestinian nationalism hardened. (Tschirgi, 1989, p. 89). When Carter launched his mission in 1977, the Palestinian issue was raised again and this time, Carter insisted that the Palestinian agenda had to be included in the peace framework. After a series of negotiations, (without PLO representatives), Carter at last successfully brought President Sadat and Menachem Begin to sign the Camp David Accords on 17 September 1978. The documents contained general principles referring to 'the legitimate rights of the Palestinian people' and the right of the Palestinians to choose their own form of government, but all the details dealt with procedures and arrangements for the transitional period only, not for the final status of the occupied territories (Quandt, 1986, p. 255; Carter, 1982, p. 319-403; Vance, 1983, p. 171).

The main objective of this paper is to analyse the British policy towards Palestinian question in the Middle East peace process during the Heath (1970-4), Wilson (1974-6) and Callaghan (1976-9) governments. Hence, the major question is either there was a dramatic change on the policy between Labours or Conservative towards the Palestinian issues during Kissinger and Carter's peace mission? Subsequently, what was the justification of the changes, if any? Or, despite the shifted of the government, did London policy in this issue remains constant and immutable? Thus to find and explain the answer, this article would analyse from historical perspectives and draws upon recently declassified British archival records supported by selected secondary sources.

With regard to the British policy and involvements, since her vital contribution as a sponsor of UN Resolution 242 in 1967 Arab Israeli War, the British government roles and participation in the Arab Israeli settlement seemed inactive and marginal. The Secretary of State for Foreign Affairs in 1977, Dr. David Owen wrote in his memoir that despite Resolution 242, Britain did not has much involvement in the peace process mainly because 'we had progressively lost influence where it counted, in Jerusalem' (Owen, 1991,p.261). Therefore, academic studies on British policy and the process of making the policy during this period, particularly regarding the Arab Israel conflict has been given less attention by scholars. (Wallace, 1977, p.vii; Vital, 1968, p. 10; Brenchley, 2005). 
From 1973 to 1979, which was a period of Dr. Kissinger and President Carter's Middle East peace missions, Britain refused to directly interfere, with the 'excuse' that she might undermine or cut across the American efforts. This is among reasons why London seems inactive through this period. Indeed, Britain admitted publicly that the peace settlement in the Middle East had to be led by the Americans, gave undivided support and was ready to provide any assistance required by Washington, such as a possibility of military backup for a United Nations (UN) peace keeping force. For example, Sir Peter Ramsbotham, the UK ambassador at Washington informed Dr. Kissinger in a meeting on March 1974 (while he recalled Sir Alec Douglas-Home's stand in 1970); that 'London would not be party to anything which will cut across US peacemaking efforts in the Middle East' (Ramsbotham, March 6, 1974).

The British Secretary of State for Foreign Affairs in 1974, James Callaghan admitted in his memoir that the US 'was the only country with sufficient 'clout' to influence both Israel and Egypt' (Callaghan, 1987, p.490). Despite her public stand of avoiding direct involvement, the result of the peace negotiation was very important for the protection and preservation of Britain's interests, particularly the flow of oil from the Middle East. The Arab oil embargo of 1973 was a bitter lesson to London and her European Allies which emphasised the importance of successful peace negotiations for creating political stability in the region to prevent another war and embargo. Sir Edward Heath, the Conservative Prime Minister from 1970 to 1974 admitted in his memoirs (Heath, 1988, p. 500), that the embargo was 'the tremendous test for the united position of the Community'. Furthermore any delay of the peace settlement would cause instability and a consequent increase of Soviet influence throughout the region. Sir Edward Heath, in a letter to President Nixon in October 1973 (Heath, 1973) expressed Britain's deeply-held concern over the threats if peace negotiations were delayed;

If there is delay, not just the Egyptians but the whole Arab world will probably retire into a shell of resentment and bitterness. In this mood, they will be inclined to try to pressurise the West into supporting their aims, while preparing themselves for another military confrontation with Israel in few years time. This will mean two things, first another opportunity for the Russians to strengthen their position by rebuilding the Arabs' military strength, secondly a progressive tightening of the oil screw as well as attacks on other Western interests in the area. We should then be faced by a stronger Soviet power base in the Middle East, accompanied by a massive economic decline of the West, and the consequent tilt to the advantage of the Communists. European economic interests would be particularly affected - but we would all suffer.

Basically, the British ultimate aim of her policy in the Middle East conflict was to achieve a 'just and durable peace' through a comprehensive settlement. Yet, London fully realized that a comprehensive settlement would not be achieved if the Palestinian issues, as one of the core problems in the Middle East conflict since before 1948 was ignored and remain unresolved. However, since the Americans were under constant pressure from pro-Israelis group regarding the Palestinians issues, the British government was placed in a dilemma. (Callaghan, 1975). A 'stand still' policy 
regarding the Palestinian questions would mean that the comprehensive settlement could not be concluded, and yet at the same time the Americans, particularly under Dr. Kissinger, avoided the Palestinian question in his negotiations and refused any attempt by the British to intervene. The option for Britain to express her voice unilaterally was considered diplomatically unwise because it might invite a great risk for the British interests, either from the Arab countries or in the US and Israel. The safest option open to London was to associate herself with the European Community (EC) as a new partner, projecting joint 'solidarity declarations', from time to time in order to safeguard Britain interests through the period of uncertain diplomatic chaos. Through this new platform, Britain expressed her policy and attitude to the world regarding the peace settlement and particularly in the Palestinian question. Edward Heath himself had a strong personal commitment to the idea of European unity (Heath, 1998, p.354-95). Heath's government policy tried to strengthen the Community by encouraging its institution in Brussels and supporting the formation of common foreign policy (Stephen, 1992, p. 35; Stephen, 1990; Stephen, 1991).

However, the successive Labour governments under Harold Wilson and James Callaghan applied a similar, if not identical policy, when it came to the Palestinian question, despite the reputation under their leadership for Britain being a 'semi-detached' member of the Community (Stephen, 1992). In his memoir, Wilson wrote that the Labour MPs were split and sharply divided on the issue of the entry to the EC. He confessed (Wilson, 1979, p.50-1), that in all my thirteen years as Leader of the Party, I had no more difficult task than keeping the Party together in this issue'. Indeed according to Wilson;

Labour MPs in the 1970-74 Parliament were against entry, many of them regardless of the terms, a smaller number opposed simply to the terms. But in the minority of Labour members who supported membership was considerable number of 'marketeers' to whom adherence to the EEC was not so much a policy as a way of life. A good number believed more strongly in British membership than in any other tenet of policy, and would, if the choice had to be made, reject the party in favour of what was to them the wider aim, Europe. (Wilson, 1979, p. 50).

\section{The Conservative Government (1970-1974)}

Dr. Henry Kissinger was appointed as a Secretary of State in September 1973 and launched his diplomatic mission for Middle East peace from November 1973. (Nixon, 1978, p. 477; Kissinger, 1979, p.348). During this period, Britain was under the Conservative party led by Sir Edward Heath as the Prime Minister and Sir Alex Douglas-Home was the Secretary of State for Foreign and Commonwealth Affairs. British government policy towards the Palestinian issue has to be seen in the context of the overall comprehensive Middle East peace settlement. The basic principles of the policy were explained by its leaders on many occasions in the 1970s. For instance, at a speech in Blackpool on October 1973 by Sir Alec Doulas-Home said;

Our basic policy in the Middle East problems remains unchanged. We stick to Resolution 242. This involves Israeli withdrawal; it involves a genuine peace; it involves 
INTERNATIONAL JOURNAL OF ACADEMIC RESEARCH IN BUSINESS AND SOCIAL SCIENCES Vol. 8, No. 11, Nov, 2018, E-ISSN: 2222-6990 @ 2018 HRMARS

secure and recognised boundaries for all states; it involves a just settlement for the Palestinians (Parsons, October 10, 1973).

These basic principles of the Conservative government policy were stated in Douglas-Home's 'Harrogate Speech' in 1970 and remained unchanged until 1974 (Parliamentary Hansard, November 15, 1973). In the Harrogate Speech, among other important points Douglas-Home explained;

How can these tensions be resolved? An equilibrium is needed in the Middle East which both sides would be prepared to accept. The actual issues in dispute are of a kind which can be solved. The fabric of a settlement consistent with the Security Council Resolution of November 1967 which would be fair and should be workable can easily be produced. Agreed solutions on all the separate elements would have to be incorporated into a formal and binding agreement which would be endorsed by the United Nations Security Council. But like the Resolution of November 1967, any such settlement must be based on two fundamental principles: the inadmissibility of the acquisition of territory by war and the need for a just and lasting peace, in which every state in the area is guaranteed the right to live in security. This means as the Security Council Resolution said, that Israeli Armed Forces must withdraw from territories occupied in the conflict; and that, on the other hand the state of belligerency which has existed in the Middle East must be ended and the right of every state to live in peace within secure and recognized boundaries, free from threats or acts of force, must be recognized. (Douglas-Home, 1970)

With regard to the Palestinian question, Sir Alex Douglas-Home in the same speech emphasized the importance of recognizing a 'legitimate aspiration - resettlement in dignity and honour' and Palestinians' desire for a 'means of self expression' as essential elements of his government policy (Douglas-Home, 1970). Subsequently, in his statement in the House of Commons on 22 October 1973, Douglas-Home, when referring to the Harrogate speech, reiterated his government view that 'the question of the Palestinians must clearly form part of a complete and long-term settlement'. Otherwise, according to Douglas-Home, 'the settlement would not stick' (Parliamentary Hansard, October 22. 1973). Although in his Harrogate speech and in the British parliament, Douglas-Home did not mention anything about either a Palestinian 'homeland' (as used later publicly in 1976 by the Labour Secretary of State, Antony Crosland) or 'a state' he thought that this could be an outcome from the peace process. In his autobiography, Douglas-Home recalled that when he drafted the speech, he thought;

Now that Egypt and the Arab countries have been purged of their humiliation by achieving a stalemate in battle; and now that there is a possible solution for the resettlement of the Palestinians in an independent State on the West Bank of the Jordan, the prospects of a permanent peace look to be more helpful than for sometime past. (Douglas-Home, 1976, p. 260).

The British policy on the Palestinian issue was also demonstrated through her support towards the European Declarations. Following Britain's entry into the European Community (EC) in 1973, British Middle East policy was developed jointly with her EC partners. On 6 November 1973, 
the Nine European States (including Britain) proclaimed the view on the Palestinian issue that was later known as the Brussels Declaration 1973. The Declaration proclaimed that in the establishment of a just and lasting peace, account must be taken of the legitimate rights of the Palestinians'. (EU Declaration, 1973; Douglas-Home, 1970). In his conversation with the Italian Prime Minister on 8 December 1973 in London, the Prime Minister Edward Heath was quoted as saying that he believe, 'If the Community could speak in one voice, it could influence both the participants (Arabs and the Israelis) and the United States' (Heath, December 8, 1973). Earlier in the House of Lords debate on 7 November 1973, Minister of State for Foreign Affairs, Baroness Tweedsmuir of Belhelvie (in office from 1972-1974) in her answer to a question from Lord Robbins stated that government support to the EC declaration was based upon the thought that 'the declaration is balanced. It puts forward, very carefully, the different interests of Israel and the Arab nations' (Parliamentary Hansard, November 7, 1973). Whilst in her answer to a question from Lord Shepherd, she explained the justification of the British government stand in supporting the Declaration,

The declaration is firmly based on Security Council Resolution 242, which the United Kingdom, together with all our partners regard as the indispensable basis for a permanent settlement. It reflects the essential balance of that resolution, between Israel's need for secure and recognised boundaries and the need of the Arabs for Israeli withdrawal from occupied territory. The declaration emphasises that in the reconciliation of these two requirements, key importance attaches to the establishment of demilitarised zones, which would need to be policed by substantial peace-keeping forces. In this respect as in others the declaration conforms to the well known views and policies of the British Government. The Nine have drawn attention to the need for the negotiations to be conducted within the framework of the United Nations. Europe and the entire international community have an interest in the achievement of a just and lasting settlement. We believe that the international community will also have an important role to play in guaranteeing the settlement. And, as my right honourable friend the Foreign and Commonwealth Secretary said yesterday in Brussels, this agreed Statement on the Middle East represents another important step in the process of evolving common attitudes towards major international problems and thus a common foreign policy. (Parliamentary Hansard, November 7, 1973).

Later in a House of Lords debate on 27 November, when answering a question from Lord Lloyd of Kilgerran, she explained that British support of the Declaration was a part of London's commitment in the European common policy;

Co-operation of foreign policy among the European Community countries is making good progress. The Declaration of the Nine issued in Brussels on November 6 is a major advance in developing a common attitude towards the Middle East problem. The views of the Nine about the basis for a permanent peace are therefore clear. This unity should enable the Community to make an important contribution towards a peace settlement. (Parliamentary Hansard, November 27, 1973) 


\section{The Labour Government (1974-1979)}

After the February 1974 general election, no party had a majority of seats in the UK parliament. The incumbent Conservative party won the popular vote, but Labour took the most seats. Sir Edward Heath, the Conservative prime minister, attempted to negotiate a coalition with the Liberal party, but resigned as prime minister after failing in this regard. The Labour Party, led by Harold Wilson (the prime minister from March 1974 to April 1976), then established a minority government which was ineffective and led to a general election six months later in October 1974 in which the Labour party gained a majority of three seats. Labour government policy on the Middle East peace settlement during this period was firmly founded on the principle of a comprehensive solution based on the UN Resolution 242, which was reaffirmed by Resolution 338 in 1973 . The ultimate aim was to 'establish a just and endurable peace in the Middle East'. (Tomeh, 1988). Harold Wilson explained British government policy towards the Palestinian question on several occasions, for instance in his letter to President Anwar Sadat of Egypt on March 1974, Wilson stated that any peace settlement had 'to offer the Palestinians a stake in the future' (Wilson, March 7, 1974).

Earlier, James Callaghan, the Secretary of State for Foreign and Commonwealth Affairs from March 1974 to April 1976 and subsequently Prime Minister until May 1979, wrote in THE TIMES on 13 February (The Times, 1974), stating that the settlement had to give the Palestinians 'satisfactory personality' and in another statement later on March 1974 that the peace settlement 'has to offer the Palestinians a stake in the future'. Subsequently, in the Queen's Speech Debate at the House of Commons on 30 October 1974 Callaghan further explained his government policy on the treatment of Palestinians in a Middle East peace settlement: 'a provision must be made for satisfaction of the needs of the Palestinians, by which I mean not only the rights of individual Palestinian refugees, as was laid down for so many years by the General Assembly, but also the legitimate rights of Palestinian people' (Callaghan, October 30, 1974). The same stance was taken by the government in international forum such as at the UN assembly. Lord Ivor Richard, the UK Representative in the UN, in his speech to the General Assembly on 22 November 1974, proclaimed to the world the British view on the Palestinian question in the Middle East peace negotiations.

It has long being my government's view that in any debate on the Middle East the views of the Palestinian people must be listened to. Indeed, I said so my self on the $14^{\text {th }}$ October in this Assembly, I quote, 'the British government has made plain many times its belief that no peace settlement in the Middle East is possible that does not take account of the legitimate rights of the Palestinians. The British Foreign Secretary has several times spoken of the need for any settlement to provide for a personality for the Palestinian people. It follows, therefore, that we consider it right that the view of the Palestinian should be heard. I would reaffirm that position today. Whatever else can be said of this debate, it would seem that a Palestinian voice has been heard clearly and unmistakeably in this assembly'. (Richard, November 20, 1974). 
INTERNATIONAL JOURNAL OF ACADEMIC RESEARCH IN BUSINESS AND SOCIAL SCIENCES Vol. 8, No. 11, Nov, 2018, E-ISSN: 2222-6990 @ 2018 HRMARS

Then, when Dr. Kissinger was still busying with his 'shuttle diplomacy' the Prime Minister declared his government's support for the American initiatives at a joint session meeting with the Senate Foreign Relations Committee and the Parliament Foreign Affairs Committee on 30 June 1975. However Harold Wilson also reminded the group that the settlement would not be fully successful without solution of the Palestinian question. According to Wilson;

The British government fully supported the step by step approach practiced by Dr. Henry Kissinger. Infinite patience was required. But the effort must be maintained. No settlement could last without a solution of the Palestinian problem. (Wilson, January 30, 1975).

In fact, with regard to Palestinian issues during the peace negotiations, the British government view was that certain additions had to be made to supplement the existing UN Resolution 242 (which had been tabled by Britain in the UN after the 1967 war) to further define the solution of the Palestinian question. This was due to the awareness that Resolution 242 referred to the Palestinian issues as refugee matters only and was therefore neither comprehensive nor reflected political scenario in the 1970s. According to the author, Frank Brenchley, who was Assistant under Secretary of State for Middle East Affairs at the Foreign Office in 1967-9:

There is only one criticism to which the Resolution is really open. This is that there was no mention of the Palestinians, except in their refugee capacity. In November 1967 it was assumed by (Lord) Caradon, and indeed by all other members of the Security Council, that an Israeli withdrawal from the West Bank (including East Jerusalem) and the Gaza Strip would be likely to mean their being handed back to Jordan and Egypt respectively. That was a natural enough assumption at the time, but it was quite rapidly outdated by the growing importance of the PLO under its chairman, Yasser Arafat. (Brencley, 2005, p. 90-1).

Nonetheless, the view that Resolution 242 should be supplemented with certain additions with regards to the Palestinian question did not mean that the British government suggested an amendment to the existing resolution. This stand was emphasized by the Minister of State for Foreign Affairs, David Ennals in early 1976 that the British government were 'not averse to certain additions being made to the provisions of Resolution 242.' (Ennals, January 29, 1976). Meanwhile, on 14 January 1976 when interviewed by the French weekly newspaper, LE POINT, Callaghan stated again (Callaghan, 1976), the British view that in the peace negotiation, 'the right of the Palestinian people to the expression of their national identity must be recognised'. Callaghan later wrote in his memoirs that whilst the Labour would not perform a 'U-Turn' in its relations with Israel, he emphasized that the Party recognised that the Palestinian people had legitimate aspirations. (Callaghan, 1987, p. 290). Subsequently, on 5 October 1976, Callaghan's successor as Secretary of State, Anthony Crosland (in office from April 1976 to February 1977) inserted this issue publicly in his speech at the UN on 5 October in which he used the unprecedented term - 'Palestinian land'. According to Crosland; 
INTERNATIONAL JOURNAL OF ACADEMIC RESEARCH IN BUSINESS AND SOCIAL SCIENCES Vol. 8, No. 11, Nov, 2018, E-ISSN: 2222-6990 @ 2018 HRMARS

A settlement must also provide a place for the Palestinians, whose fate is at the very heart of the Middle East dispute. They regard themselves and are now generally recognised, as people distinct from their Arab neighbours, with their own strong aspirations towards nationhood. One essential element in a settlement will be a land for Palestinians, not necessarily a sovereign state but a place where they will be free to look after their own affairs. (Crosland, October 5, 1976).

Crosland further elaborated on his statement in a letter to one of his parliamentary colleagues, Colin Jackson MP on 26 November regarding the term 'Palestine land';

My qualifying phrase about such a land being 'not necessarily a sovereign state' was certainly not meant to rule out the possibility that a sovereign Palestinian state might result from a negotiated settlement; if this in fact happened, we should welcome it unreservedly. But in my view it would be wrong for us at this moment to try to prejudge or seek to prescribe the outcome of those negotiations; that is why I added a qualifying phrase. (Crosland, November 26, 1976)

When James Callaghan replaced Harold Wilson as the new Prime Minister in May 1976, government policy remained unchanged but this time Callaghan reinstated his government's view that the Palestinian issue was not just a refugee matter and gave a clearer hint as to what the British government meant by the 'Palestinian homeland'. In his speech to the Board of Deputies of the British Jews at Upper Woburn Place, London on Sunday, 23 October 1977:

There is no prospect of a lasting peace coming about in the Middle East unless the Palestinian problem is solved. We believe the way to solve it is by setting up a homeland of some kind for the Palestinian Arabs. It is not for us to say what form that homeland should take. That is the matter for the parties concerned. But it is obviously cannot just be in Jordan. There are over a million Palestinians in the West Bank and the Gaza Strip who would neither be absorbed by Jordan nor would wish to be uprooted from their present homes. Most of these people are not refugees (Callaghan, October $\left.23^{\text {rd }}, 1977\right)$.

As mentioned earlier, other than unilateral statements, the policy of the British government was also clearly demonstrated through her firm support of the EC declarations. Britain's view accorded with those of her EC partners; that the issue of Palestinian rights should not be excluded in any peace negotiations led by the Americans. There was a general perception that the British Labour government might behave differently compared to the Conservatives due to its closer traditional relations with the Labour government in Tel Aviv; and with its reputation for being a 'semi-detached' member of the Community, with continuous arguments and disputes in many areas towards the EC policies. But in fact, the Labour government as with its predecessor firmly supported EC policy on Palestinian issues including the Brussels Declaration of 1973. 
INTERNATIONAL JOURNAL OF ACADEMIC RESEARCH IN BUSINESS AND SOCIAL SCIENCES Vol. 8, No. 11, Nov, 2018, E-ISSN: 2222-6990 @ 2018 HRMARS

The Secretary of State, James Callaghan in 1974 admitted openly that, 'the Labour government did not dissent from the European Declaration' (Callaghan, May 1974). While in a phone conversation with the Israeli ambassador to the UK, Mr. Gideon Rafael on 27 March 1974, Callaghan was recorded as saying that the reason of his government's support of the Declaration was that it was 'the easiest way to calm Arab feeling' and the declaration 'was primarily an endorsement of Resolution 242 and 338'. (Callaghan, March 27, 1974). He also wrote a message to the Israeli Foreign Minister, Mr. Abba Eban on April 1974 justifying British support for the Declaration. According to Callaghan in his message, one of the main reasons was to avoid Arab hostile policy against Britain, but also he said that such a hostile Arab response would jeopardise British interests in the Arab world. He told Eban: 'it will not help you [Israel] if we damage ourselves where there is no need to do so' (Callaghan, April 1 ${ }^{\text {st }}, 1974$ ). In addition, Mr. David Ennals, Minister of State for Foreign Affairs wrote letters to British parliamentary members for example to Mr. Keith W. Stainton, a Conservative MP for Sudbury and Woodbridge dated 31 May 1974, explaining that Labour policy over the Brussels Declaration;

We regard the European Declaration as essentially a re-statement of the most important elements in a peace agreement as set out in Resolution 242. We do not consider that it affects the provisions of that Resolution. (Ennals, May 31 ${ }^{\text {st }}, 1974$ ).

On later occasions, the British government also supported publicly the European Council declaration issued in the presidency's speech to the UN General Assembly on 7 December 1976 in which the Nine reaffirmed, 'We have...made clear that the exercise of the right of the Palestinian people to the effective expression of its national identity could involve a territorial basis in the framework of a negotiated settlement' (Foreign and Commonwealth Office's Paper, 1983). A few months later, on 29 June 1977 Britain and the Nine declared again at the UN that 'we have affirmed our believe that a solution in the Middle East will be possible only if the legitimate right of the Palestinian people to give effective expression to its national identity is translated into fact, which would take into account the need for a 'homeland' for the Palestinian people'.

The new Secretary of State for Foreign Affairs, Dr. David Owen who replaced Anthony Crosland (in office from February 1977 to May 1979) defended vigorously his government's policy to support such declarations, as he mentioned in the House of Commons on 13 July 1977;

The statement issued by the Nine on 29 June demonstrates the importance which the European Community, including the United Kingdom, attaches to an urgent resumption of peace negotiations. (Parliamentary Hansard, 1977).

Dr. Owen further justified his government support to the declaration, which he described as 'a balance' approached (while Alec Douglas-Home in his Harrogate's Speech in 1970 used the term equilibrium);

The statement must be read as a whole. It rightly pays attention to the 'Palestinian homeland' and the question of territories occupied by Israel. It also draws attention 
INTERNATIONAL JOURNAL OF ACADEMIC RESEARCH IN BUSINESS AND SOCIAL SCIENCES Vol. 8, No. 11, Nov, 2018, E-ISSN: 2222-6990 @ 2018 HRMARS

to the quality of the peace in the Middle East and the right of Israel to exist. It may be said by some that these are conflicting statements, but I do not think so. (Parliamentary Hansard, 1977).

When President Carter and his team were orchestrating peace negotiations between the Israelis and the Arabs, the British Prime Minister re-emphasized the importance of taking account of Palestinian issues in the negotiations. The Prime Minister James Callaghan (from 1976-May 1979) insisted this issue to President Sadat in their meeting at Aswan on 13 January 1978 that;

It will be necessary to involve the Palestinian people in the negotiations and the implementation of a settlement, and in the determination of their future within a homeland of their own taking into account the fundamental interests of the other people and states involved in a peace settlement. (Owen, March, 30 ${ }^{\text {th }}, 1978$ ).

Subsequently, on March 1979, when debating the issue of the peace negotiations in the Middle East in the House of Commons, the Secretary of State Dr. David Owen restated his government's policy towards the Palestinian question, and this time he clearly expressed the government's full support for the concept of 'Palestinian autonomy' in the West Bank and Gaza. In a statement given to parliament, Dr. Owen explained that it was his government's policy that, 'we believe there must be a Palestinian homeland if there is to be a comprehensive peace settlement. We see as the first step towards that settlement full autonomy on the West Bank and Gaza' (Parliamentary Hansard, March $\left.21^{\text {st }}, 1979\right)$.

\section{The PLO and the West Bank questions: A policy}

An understanding of the British government policy towards the Palestinian question turns on the crucial issues of the PLO and the West Bank. The status of the PLO as 'a sole legitimate representative of the Palestinian people', as unanimously endorsed by the Arabs at the Rabat Summit on October 1974, did not influence the British to either recognise or establish an official contact with the organisation. However, the status afforded the PLO by the Arabs did have an effect on the British government policy to support the 'Palestinian legitimate rights and homeland'. The policy of not recognising the PLO was expressed and mentioned by the British government on many occasions. This was demonstrated, for example, when the PLO proposed to open an office in London in 1972. At that time, the British government did not refuse an application by the PLO to open its office in London due to a legal consideration.(Heath, July 17, 1972; Godber, July 6, 1972; Judd, October 23 ${ }^{\text {rd }}$, 1978). However, she firmly rejected any possibility to accord official recognition towards the organisation. This was stated clearly, for instance in a message from Sir Alec Douglas-Home to the Israeli Foreign Minister on 29 June 1972 that there has no question they [PLO] 'will enjoy any kind of official or quasiofficial status from the government' (Douglas, Home, June 29, 1972). Later on 6 July 1972, the same statement was made in parliament by the Minister of State for Foreign Affairs, Mr. Joseph Godber (Parliamentary Hansard, 1972). Nevertheless the British government refused to expel the PLO representative, Said Hammami, at the Arab League office from London. According to Douglas-Home; 
INTERNATIONAL JOURNAL OF ACADEMIC RESEARCH IN BUSINESS AND SOCIAL SCIENCES Vol. 8, No. 11, Nov, 2018, E-ISSN: 2222-6990 @ 2018 HRMARS

I should not wish to provoke the very hostile reaction that would undoubtedly be caused in the Arab world if we were to expel the representative of an organisation which has now been recognised by almost the all Arab states as the sole legitimate representatives of the Palestinians and whose organisation sits as a full member of the Arab League (Douglas-Home, January 10, 1974).

The Labour government position from 1974 to 1979 was similar to that of the Conservatives. For instance, in 1975 when interviewed by the ABC TV in the 'Issues and Answer' programme screened on 2 February, the prime minister, Harold Wilson when referring to the issue of dealing with the PLO firmly stated that, "but so far as this is concerned, we cannot negotiate with men who have got blood on their hands and they know it well' (ABC TV, 1974). Whilst at the House of Commons on 25 June, the Secretary of State, James Callaghan explained that 'the leaders of the PLO have not yet recognised the existence of the state of Israel. In those circumstances, I find it difficult to meet them' (Parliamentary Hansard, June 25, 1975). Whilst Minister of State for Foreign Affairs, Mr. Frank Judd in a letter to his parliamentary colleagues John Gorst, MP on 3 October 1977, (Judd, 1977), emphasized that although the British did not recognise the PLO, 'We believe that the views of all Palestinians, including the PLO must be taken into account in reaching a just settlement'. In fact in another letter to Mr. Andrew Faulds, MP on 7 December 1977 (Judd, 1977), Mr. Judd explained vividly the government stand on the policy of unrecognising the PLO and ruled out of any possibility of contact with the organisation because of the PLO stand of does not accepted the UN Resolution 242 and its Charter, which still denied the Israel's right to exist. The Secretary of State for Foreign Affairs in 1978, Dr. David Owen also explained the Labour government policy in his letter dated 27 November 1978 to the prominent Jewish leader in Britain, Mr. Eric Moonman that 'I can assure you that there is no question of our 'recognising' the PLO, so long as their formal position remains that they refuse to accept Israel's right to exist' (Owen, 1978).

Other than to consider the strong objection of the Israelis, one of the major reasons of the British refusal to recognise the PLO, was the consideration that such recognition would conflict with her existing policy towards Jordan and Israel. A move by the British to recognise the organisation might risk a possibility of the PLO claiming the status of 'government' or a 'government in exile'; a status which definitely would not be accepted by London. Therefore since the Conservative period, the British government steadily supported the attitude taken by Dr. Kissinger of not negotiating with the PLO in the peace process. The Foreign and Commonwealth Office explained the reasons beyond the government policy in 1974;

We do not accept that the PLO constitute a government, even thought it has been accepted as a full member of the Arab League and by the Arabs, and the Moslems at their respective summits as the sole legitimate representative of the Palestinian people. There is a possibility that the PLO may declare itself a Palestinian governmentin-exile; if it does we be faced with a difficult legal problem. First we have reconsidered King Hussein de jure sovereignty over the West Bank, secondly, even if King Hussein were to wash his hands of the West Bank, our criteria for the recognition of a 
government would make it very difficult for us to recognise one which not only did not control any territory but did not even agree within itself what territory it wished eventually to control. (Chalmers, March 28, 1974).

Britain under Labour shared the same reasons, applied a similar policy of not recognising the PLO and rejected the concept of 'Palestinian government in exile'. Since Britain avoiding any attempt of giving the status either of government or state to the PLO, Britain abstained at the UN vote on the UN General Assembly, Resolution 3210 inviting the PLO to Participate in UN Debates on Palestine, on 14 October 1974. London gave a technical reason to justify her position to abstain (as mentioned at the UN and later at the House of Commons) that the 'PLO is an organisation and not a government who should address the Assembly' (Parliamentary Hansard, 1974).

The next issue in regard to the Palestinian question was the issue of the Israeli occupation of Arab lands, particularly the West Bank, which was occupied since 1967. Under the Kissinger plan, the West Bank should be negotiated between the Israel and Jordan while Carter had proposed the idea of autonomy administration by its inhabitants. (Zbigniew, 1983, p. 85-7; Carter, 1982, p. 280; Sicherman, 1978. P. 34). At the beginning under the Conservatives, Britain did not accept the possibility of recognizing Palestinians claim over the West Bank which she found incompatible with her policy towards Israel and Jordan. Since the 1950s, British policy was that the West Bank (including East Jerusalem) should reside under the sovereignty of Jordan, as stated by the Minister of State for Foreign Affairs, Mr. Kenneth Younger on April 1950. The British admitted that the existence of the Anglo-Jordanian Treaty of Alliance (abrogated in 1957) was a powerful reason for doing this. In his statement to the House of Commons on 27 April 1950, Mr. Younger proclaimed that;

His Majesty's Government in the United Kingdom have been officially informed by the Government of the Hashemite Kingdom of Jordan of the union of the Kingdom of Jordan and of that part of Palestine under Jordanian occupation and control. The Jordan Government, in this communication, have stated that an Act providing for this union was unanimously adopted on 24th April by the Jordan Assembly, which is composed of representatives of both these territories, and received the Royal Assent on the same day. His Majesty's Government have decided to accord formal recognition to this union. They take this opportunity of declaring that they regard the provisions of the Anglo-Jordan Treaty of Alliance of 1948 as applicable to all the territories included in the union. (Parliamentary Hansard, 1950; Craigh, January $22^{\text {nd }}, 1975$ ).

As in 1950, the same sentiment was shared and similar attitude applied later in 1973. According to the FCO in 1973;

First there are some clear limitations in our policies. We would not embark on any course which was hostile to the sovereignty and integrity of states which we have normal, indeed close and friendly relations. Thus, we would obviously have no truck with the 'multinational secular states' ideas of the Palestinian Organisations. Such ideas are wholly incompatible with our attitude towards Israel. We equally cannot afford to have any truck with the idea of separate independent Palestine State on the West Bank, with or without Gaza. This concept, so long as it is opposed by the 
Jordanian government, is incompatible with our recognition of Jordanian sovereignty over the West Bank. For us to be seen to be espousing this idea would be anathema to King Hussein (Parsons, May $2^{\text {nd }}, 1973$ ).

Additionally, based on an FCO's assessment paper in 1973, the British believed that many Palestinian refugees wished to settle in the West Bank and Gaza once the Israeli occupation was over. However, the FCO admitted that the British could not support any plan for a Palestinian entity in these areas because it would be incompatible with her recognition of Jordanian sovereignty over the West Bank. Therefore, the nearest thing that Britain could come to this would be to support King Hussein's plan for a United Arab Kingdom which would comprise a Jordanian region on the East Bank and a Palestinian region on the West Bank linked with a corridor to Gaza (Parsons, October $2^{\text {nd }}, 1973$ ). This thought was widely supported at the UN. For example during Gunnar Jarring's mission for the UN after the 1967 War, Palestinian representation was not considered because it was assumed that the West Bank (or a large part of it) would at some time return to Jordanian sovereignty. (Brenchley, 2005, p. 96). Despite the view that the issue of the West Bank should be negotiated between Israel and Jordan, Britain did not compromise in her policy that Israel must withdraw her troops from the occupied Arab lands in accordance with UN Resolution 242. In his famous Harrogate speech of 1970, Sir Alec Douglas-Home stated British policy based on the principle of 'the inadmissibility the acquisition of territory by war' and that therefore 'the Israeli Armed Forces must withdraw from territories occupied in the conflict'. Furthermore, according to Douglas-Home, 'secure and recognised boundaries should be based on the Armistice Line which existed before the war of 1967 subject to minor changes which might be agreed between the two countries'. (Douglas-Home, 1970; Parsons, October 24, 1973). Later, in his autobiography, Douglas-Home recalled that when he drafted the Harrogate Speech, he had thought that the settlement was bound to involve substantial withdrawal of Israeli forces (with minor adjustment). Home also wrote;

I was well aware that it was impossible to please both sides. Predictably the Arabs were welcoming and the Israelis angry; the more so as they had thought that I was sympathetic to them in the fight for their existence. In the latter feeling they were right; and the speech stemmed from the conviction that their only hope of survival in an age of missiles lay in abandoning their conquered Arab territories, and in retiring behind their 1967 frontiers which would be then be policed by the United Nations, and would probably require an international guarantee. (Douglas-Home, 1976, p. 258).

It was clear here that the British government under the Conservatives after 1970 insisted that the Israelis withdraw from the Arab territories occupied by war, including the West Bank. However, from the British view, this process had to be negotiated between the Israelis and the Jordanian government rather than the Palestinian inhabitants.

Eventually, the British government view in 1974 was changed and modified so that, despite of the Israelis, the future of the West Bank should be negotiated between King Hussein and the West Bankers. Under Labour, the British government supported the concept of West Bank autonomy administrated by the Palestinians as proposed in the Camp David Accords 1978. (Quandt, 2001, p. 273; Carter, 2006, p. 46). Therefore, the British government opposed the Israeli policy of retaining 
the occupied territories as well as objecting to the settlement policy to change the demographic character of the areas, particularly the West Bank and Jerusalem. Indeed, the British government disagreed with Israeli claims that occupation of the territories was vital for her security. The Secretary of State, James Callaghan described the details of the British policy and attitude on his speech in London on 23 October 1977. In his statement (Callaghan, October 23 ${ }^{\text {rd }}, 1977$ ), Callaghan stressed that he did not believe that Israeli security could be guaranteed indefinitely by the occupation of territory. For him and his government, this action would be a standing invitation to continue tension and the danger of renewed war. In the British view, the borders of a state must be geographically relevant but the possession of territory was no longer the only security factor with the development of modern weapons that had become even more marked. Whilst Dr David Owen, the Secretary of State in 1978, further insisted his government call on the Israelis to withdraw from territories occupied since 1967 including the West Bank. In a statement in Parliament on 22 October 1978, Dr Owen said;

It is the government's view, as it has been of successive British government that withdrawal from all three areas - Golan, the West Bank and Sinai - is part of interpretation of Resolution 242. We have also consistently reiterated our determination that Israel should have secure boundaries. (Parliamentary Hansard, 1978)

In regard to the Palestinian question, the British government also firmly rejected Israel's settlement policy in the occupied lands. For instance, when Menachem Begin came to power on June 1977, his government legalised three settlements on the occupied West Bank and authorised the establishment of thirteen more. Most of these appeared to have been set up by civilians within existing army camps. The Israelis implied that no more settlements would be allowed while peace talks continued, but there were no clear commitments to this effect. In fact, General Sharon (Minister of Agriculture) spoke of settling two million Jewish immigrants on the West Bank. Suffice to state here that by 1977 there were 33 settlements in all on the West Bank and 25 on Golan Heights. There were also 21 in the Rafah salient (near Gaza) and in Sinai. They housed some 10,000 settlers. By early 1978, Israel had constructed sixty-two settlements in the occupied areas. (Lesch, 1978, p.119). Demographic changes also strikingly reflected Likud policy. The Jewish population of the West Bank was only 3,176 by the end of 1976 . This figure rose in 1978 to over 7,000 and to 10,000 in 1979 . By the end of 1983 the Jewish population was 27,500. (Bevensiti, 1984, p. 61). On this issue the British government clearly expressed her objection to Israeli government policy. For example, in a letter to Andrew Faulds, MP on 10 October 1977, the Minister of State for Foreign Affairs, Mr. Frank Judd justified the British government objection to Israel's settlement policy;

We as a Government have made clear that we reject the Israeli policy of establishing settlements in the occupied territories, and we have voted for UN Resolutions condemning this policy. We have also left the Israeli government in no doubt that we regard their recent decision to give permanent status to three settlements on the West Bank as compounding the difficulties of bring peace to the area (Judd, 1977). 
Indeed the UK with the rest of the EC voted on 28 October for the UN resolution deploring Israel's settlements policy. The objections to the Israeli settlements were firstly that they made Israel's good faith in entering peace negotiations suspect; and secondly that they contravened Article 49 of the Fourth Geneva Convention (which makes it illegal for an occupying power to deport or transfer parts of its own population into the territory it occupies) (Powel, November 29, 1977; Goronwhy, August 15, 1978). The British government under Labour applied a firm policy that Israel had to withdraw from territories she had occupied since 1967 and opposed Israeli policy to change the demographic character of the area through her illegal settlement policy. In fact, the British government publicly supported the proposal that the West Bank should be administrated by the Palestinians under the autonomy concept as proposed by President Jimmy Carter in the Camp David Accords of 1978.

\section{Conclusion}

From 1973 to 1979, the U.S Secretary of State, Dr. Henry Kissinger and then President Jimmy Carter tirelessly brokered unilateral peace negotiations between the Arabs and the Israelis. In the negotiation frameworks, a list of agreements were signed, namely the Sinai Agreements and the Camp David Accords. These agreements were considered important stepping stones towards a more comprehensive peace settlement in the future. Indeed, these efforts prevented a repeat of the October 1973 war. Through the extensive negotiations several issues were solved, particularly the dispute between Egypt and Israel over Sinai and the Suez. However, the negotiations were fruitless in achieving a comprehensive solution to the Palestinian question. Although during Carter's mission there were agreements on Palestinian issues especially the general principle referred to 'the legitimate rights of the Palestinian people' and the right of the Palestinians to choose their own form of autonomy government, but all the details dealt with procedures and arrangements for the transitional period only, and not with the final status of the occupied territories. Ironically, the Palestinians were excluded from all of the process of self determination. The only Palestinian representative at that time, the PLO, which was recognised as the sole legitimate representative of the Palestinian people by the Muslim world, was totally excluded from the negotiations. The Palestinians however were unofficially represented by the Egyptians and King Hussein of Jordan through the period of negotiations. The Americans on the other side faced great obstacles in dealing with Palestinian representatives due to pressure from the Israelis and from pro-Israeli groups at the State. As a consequence of this American dominance of the peace process, their roles and policy have received wider attention from eminent scholars debating and writing about the history of international relations in the modern Middle East.

In Britain, the Palestinian questions were seen by London as the backbone issue in any efforts to solve the Middle East conflict. The British government's basic policy was that any Middle East conflict negotiations had to be comprehensive for a 'just and durable peace settlement'. Britain firmly believed in the principle of 'equilibrium and co-existence' approaches towards all the parties concerned. On one side, there should be recognised boundaries and a guarantee of safety for the Israeli state and at the same time there was a need to recognise Arab rights. On the latter principle, the British government also called persistently and publicly for all parties to recognize the legitimate 
rights of the Palestinians. For the British government, one of the main rights of the Palestinians was to have their 'homeland'. This policy was projected through speeches and attitudes by the prominent British leaders openly on many occasions. The entry of Britain into the European Community in 1973 created a further platform for London to express her concern and policy towards the Palestinian question. In spite of her close friendship with Tel Aviv, the Brussels Declaration of November 1973, which called for public recognition of Palestinian rights, received unanimous support from the EC, including Britain. Subsequently, London steadily projected her support for all declarations proclaimed by the EC regarding the Palestinian question until 1979.

The attitude of the British government in certain circumstances towards the EC was slightly different between the Conservatives under Edward Heath and Labour under Harold Wilson and James Callaghan. Whilst Heath's government was seen as pro EC, the successive Labour governments had a reputation of holding a 'semi detached' attitude towards the Community. At the same time, the election of Labour in 1974 was received with suspicion by the Arabs due to the party's traditionally close relationship with Israel. However, in spite of the distinguishing image, reputation and background, the Conservative and Labour governments shared a similar view and common policy towards the Middle East peace process, particularly regarding the Palestinian question. Although the terminologies used by them varied from time to time - such as Palestinian personality, Palestinian rights, Palestinian stake and Palestinian homeland - British governments under Conservative and Labour from 1970 to 1979 were in agreement on policy, objectives and principles and on semantic interpretation of their official statements on the Middle East peace negotiations. Both governments agreed to support, unilaterally and jointly with the EC, a call to all parties to recognize Palestinian legitimate rights, the Israeli withdrawal from occupied territories, Palestinian autonomy in Gaza and the West Bank and the full implementation of all principles as laid down in UN Resolution 242 and 338. Ironically, both governments whilst supporting firmly Palestinians rights, refused to recognise or to deal with the PLO

Through the period of Kissinger and Carter, Britain under Conservatives and Labour give undivided support to the American efforts but at the same time avoided taking any movement or action which could be considered as direct interference or might cut across Washington's unilateral diplomatic missions. Yet, this should not be fairly interpreted as either a standstill nor unsupportive approach, but should be seen as a wise, unique and flexible diplomatic strategy to complement and sometimes substitute when, due to international and domestic political constraints the Americans were unable to push and press the conflicted parties for a common consensus. For instance, on the issue of the Palestinian question, when the Americans was under pressure not to declare publicly support for Palestinian rights, particularly during the Kissinger era and during American presidential election campaign periods, Britain with her European allies appeared to balance the image and voice of the Western governments with their continued public declarations. These declarations were helpful in maintaining the momentum of negotiations in the absence of the Americans and indirectly calmed the anger of the Arabs and the entire Muslim world. While the world welcomed and applauded the American peace initiatives from 1970 to 1979, Britain's policy should not be forgotten 
when writing the modern history of international relations in the Middle East, particularly on the Arab-Israel peace negotiations.

Finally, the major and most significance contribution of this study is the finding that Britain was very consistent in her policy towards the Palestinian issues. Although there were changes of the government between Labour and Conservative, the core of British policy remains unchanged. In addition to the existing study, this article proposes that the role of Britain after 1960s in the ArabIsrael conflict was still relevant despite the US domination of orchestrating the peace plan by Carter and Kissinger. In fact, London appeared as an important ally to Washington in the peace process with her effective, yet a unique diplomatic strategy. In this regards, a combination of unilateral strategy and collective approaches with the EU projected a wise diplomatic policy by Britain when dealing with the sensitive conflict of the Middle East. Nonetheless, this study proposes that London deserves at least a token of credit and attention from scholars in acknowledgement of her balanced, brave, steady and open support over the Palestinian question.

\section{References}

Benvensiti, M. (1984). The West Bank Data Project: A Survey of Israeli's Policies. Washington D.C : AEI Press.

Brenchley, F. (2005) Britain, The Six-Day War and Its Aftermath. London: I.B Tauris

Callaghan J. (October 14, 1974) UK's Explanation Note of her abstain in the UN in a telegram no. 837 from Callaghan to UK Missions abroad (File FCO 93/548) The National Archive, London.

Callaghan, J. ( October 30, 1974) A statement by Mr. Callaghan on the debate of Queen's Speech, House of Commons ( File FCO 93/547) The National Archive, London.

Callaghan, J. (1987). Time and Change. London: Collins.

Callaghan, J. (April $1^{\text {st }}, 1974$ ) A message from Callaghan to Abba Eban- enclosed in a letter from A.A. Acland, FCO London to Mr. Gidean Rafael. (File FCO 93/522) The National Archive, London.

Callaghan, J. (January 14, 1976) A transcript of the Secretary of State interview with French weekly news, "Le Point" In (File FCO 93/953) The National Archive, London.

Callaghan, J. (March 12, 1974) Statement in The Times, dated 13 February, Enclosed in a telegram no. 175 (File FCO 93/545) The National Archive, London.

Callaghan, J. (March 27, 1974) A record of phone conversation between James Callaghan and Mr. Gidean Rafael, in a telegram no. 69 (In file FCO 93/521) The National Archive, London.

Callaghan, J. (May, 1974) A record of conversation between Callaghan and Mr. Alderman Michael Filder, MP (File FCO 93/546) The National Archive, London. 
INTERNATIONAL JOURNAL OF ACADEMIC RESEARCH IN BUSINESS AND SOCIAL SCIENCES

Vol. 8, No. 11, Nov, 2018, E-ISSN: 2222-6990 C 2018 HRMARS

Callaghan, J. (October $23^{\text {rd }}$, 1977) A text of the Prime Minister, James Callaghan's speech (File FCO 93/1217) The National Archive, London.

Callaghan, J. (October $23^{\text {rd }}, 1977$ ) Text of speech by the Prime Minister, James Callaghan. (File FCO 93/1217). The National Archive, London.

Carter, J. (1982a). Keeping Faith: Memoirs of a President. New York: Collins

Carter, J. (2006b) Palestine Peace Not Apartheid. New York: Simon \& Schuster

Chalmers, G. (March 28, 1974) A letter from G. B Chalmers, FCO to Sir J.L Pumprey KCMG, UK High Commissioner to Pakistan, Islamabad (File FCO 93/485) The National Archive, London.

Craig, A. (January $22^{\text {nd }}, 1975$ ) A statement regarding the Anglo-Jordanian Treaty in a minute from A.J.M Craig, NENAD to Mr. Weir (File FCO 93/744) The National Archive, London.

Crosland, A. (November 26, 1976) A letter from Anthony Crosland to Colin Jackson. (File FCO 93/956) The National Archive, London.

Crosland, A. (October 5, 1976) A speech by the Secretary of State for Foreign and Commonwealth Affairs, Antony Crosland at the UN General Assembly. (File FCO 93/956) The National Archive, London.

Cyrus Vance. (1983). Hard Choices: Critical Years in America Foreign Policy. New York: Simon \& Schuster.

Douglas-Home, A. (1976). The Way the Wind Blows: An Autobiography by Lord Home. London: Collins.

Douglas-Home, A. (January 10, 1974) A letter from Sir Alec Douglas-Home to the Home Secretary (File PREM 15/2090) The National Archive, London.

Douglas-Home, A. (June 29, 1972) A message from Sir Alex Douglas Home to Abba Eban in Telegram.no 347 (file FCO 17/162) The National Archive, London.

Douglas-Home, A. (October $31^{\text {st, }}$ 1970) Text of speech by The Rt.Hon. Sir Alec Douglas-Home in Yorkshire Provincial Area Meeting (Conservative Party) at Harrogate on Saturday, (File FCO 93/212). The National Archive, London.

Ennals, D. (January 29, 1976) A record of conversation between the Minister of State with the Saudi and Syria Ambassador (File FCO 93/953) The National Archive, London. 
INTERNATIONAL JOURNAL OF ACADEMIC RESEARCH IN BUSINESS AND SOCIAL SCIENCES Vol. 8, No. 11, Nov, 2018, E-ISSN: 2222-6990 C 2018 HRMARS

Ennals, D. (May 31 $\left.{ }^{\text {st }}, 1974\right)$ A letter from Mr. David Ennals, MP to Keith W. Stainton, MP, House of Commons. (File FCO 93/546) The National Archive, London.

Foreign and Commonwealth Office, (October 24, 1973) The FCO paper, 'Britain and Middle East Settlement' enclosed in a minute from A.D Parson (File FCO 93/207) The National Archive, London.

Foreign and Commonwealth Office, UK (January, 1983) The FCO's Paper entitles, 'Britain and the Arab Israel Dispute' (File FCO 973/280) The National Archive, London.

Godber, J. (July 6, 1972) A written statement by the Minister of State, Mr. Joseph Godber in - Hansard, Col. 204-5, Vol. 840 (File FCO 17/1615) The National Archive, London.

Godber, J. (July 6, 1972) An answer from Mr. Joseph Godber, Minister of State for Foreign Affairs to a question from Mr. Kaufman, MP, extraction from Hansard, Col. 204-205, Vol. 840 (File FCO 17/1615) The National Archive, London.

Gorowny R. (August 15, 1978) An explanation given in the letter from Minister of State, Lord Goronwy Robert on behalf of Dr. Owen to Mr. Frank Hooley,MP (File FCO 93/1693) The National Archive, London.

Heath, E. (1998) The Autobiography of Edward Heath: The Course of My Life. London: Hodder \& Stoughton.

Heath, E. (December 8, 1973) Extract of a record of conversation between the Prime Minister and the Italian Prime Minister. (File PREM 15/1768) The National Archive, London.

Heath, E. (July 17, 1972) Explanation letter from the Prime Minister Edward Heath to Sir Marcus (file PREM 15/2090) The National Archive, London.

Heath, E. (November 15, 1973) Statement by the PM in Hansard, 15 November 1973, Vol. 864, cc65861. United Kingdom.

Judd, F. ( October $3^{\text {rd }}$, 1977) A letter from Mr. Judd to John Gorst, MP (File FCO 93/1223) The National Archive, London.

Judd, F. (August 10, 1977) A letter from Frank Judd to Andrew Faulds, MP. (file FCO 93/1223) The National Archive, London.

Judd, F. (December 7, 1977) A letter from Frank Judd to Andrew Faulds MP (File FCO 93/1223) The National Archive, London.

Judd, F. (October 23 ${ }^{\text {rd }}$, 1978) A letter from Minister of State, Mr. Frank Judd to Greville Janner, Q.C, MP (File FCO 93/1562) The National Archive, London. 
INTERNATIONAL JOURNAL OF ACADEMIC RESEARCH IN BUSINESS AND SOCIAL SCIENCES Vol. 8, No. 11, Nov, 2018, E-ISSN: 2222-6990 C 2018 HRMARS

Judd, F. (October $3^{\text {rd }}$, 1977) A letter from Frank Judd to John Gorst, MP (File FCO 93/1223) The National Archive, London,

Kissinger, H. (1979). White House Years. London: Weidenfeld \& Nicolson and Michael Joseph

Lesch.M. Ann (1978). Israel Settlements in the Occupied Territories. Journal of Palestine Studies, 8 (1), 119

Matti Golan. (1976). The Secret Conversation of Henry Kissinger. New York: Quadrangle.

Nixon, M. (1978). The Memoir of Richard Nixon. New York: Grosset \& Dunlap

Owen, D. (1991). Time to Declare. London: Michael Joseph.

Owen, D. (July 13, 1977) A statement by the Secretary of State for Foreign and Commonwealth Affairs, Dr. David Owen at the House of Commons, 13 July 1977- Hansard, Col. 401/403, Vol. 935, 13 July 1977 (File FCO 93/1218) The National Archive, London.

Owen, D. (March 22 ${ }^{\text {nd }}, 1978$ ) Oral answer by Dr. Owen in parliament- Hansard. Col. 1493/1497, Vol. 946 (File FCO 93/1684) The National Archive, London

Owen, D. (November 27, 1978) A letter from Dr. David Owen to Mr. Eric Moonman, Chairman of British Zionist Federation (File FCO93/1562) The National Archive, London.

Parliamentary Hansard (1973). Vol. 86. Cc 658-61, Vol. 861- cc697, Vol. 346- cc 355-64, Vol. 347-cc14. London: The National Archive, London.

Parliamentary Hansard (1975). Vol. 894, cc. 422 London: The National Archive, London.

Parliamentary Hansard (1977). Vol. 861-cc 697-705. London: The National Archive, London.

Parliamentary Hansard (1978). Vol. 946-cc1493-1497. London: The National Archive, London.

Parliamentary Hansard. (1972). Vol. 840. Col. 204-205.London: The National Archive, London.

Parsons, A.D (October 10, 1973), An extraction of a speech by the Secretary of State, Sir Alec DouglasHome at Conservative Conference on The Middle East issue, as attached in the memo by A.D Parsons. (File FCO 93/205) The National Archive, London.

Parsons, D. (May $2^{\text {nd }}, 1973$ ) A letter from A. D Parsons, FCO to P.H.G Wright Esq. (File FCO 93/485) The National Archive, London. 
INTERNATIONAL JOURNAL OF ACADEMIC RESEARCH IN BUSINESS AND SOCIAL SCIENCES

Vol. 8, No. 11, Nov, 2018, E-ISSN: 2222-6990 C 2018 HRMARS

Powel, D. (November 29, 1977) A Brief no 2- a visit of the Prime Minister of Israel, 2-4 December 1977- a minute from CD Powel, NENAD to PS Mr. Judd (File FCO 93/1222) The National Archive, London.

Quandt, W. (1986a).Camp David Peace Making and Politics. Washington: Brookings Institute Press.

Quandt, W (2001b). Peace Process: American Diplomacy and the Arab Israeli Conflict Since 1967. Washington: Brookings Institution Press.

Rambostham, Sir. P (March, 6, 1974). Note of meeting between HM Ambassador and Secretary of State Kissinger. (File FCO 93/497), The National Archive, London

Richard, I. (November 20, 1974) Extract of speech made by Sir Ivor Richard at the UN Assembly (file FCO 93/518) The National Archive, London.

Sheehan, E. (1976). The Arabs, Israelis and Kissinger. New York: Readers Digest Press.

Sicherman, H. (1978). Broker or Advocate: The U.S. Role in the Arab-Israel Dispute, 1973-1978. Philadelphia: Foreign Policy Research Institute.

Stephen, G. (1990a) An Awkward Partner: Britain in the European Community. Oxford: Clarendon Press.

Stephen, G. (1991b). Politics and Policy in the European Community. $2^{\text {nd }}$. Ed. Oxford: Oxford University Press.

Stephen, G. (1992c). The Policy of British Government within the European Community. In Britain and the European Community. Oxford: Clarendon Press.

Tomeh, G. et.al. (1988). United Nations Resolutions on Palestine and the Arab Israeli Conflict, 19471974. Washington, D.C: Institute for Palestine Studies.

Tschirgi, Dan (1989). The American Search for Mideast Peace. New York: Praeger

Ullman, R. (1975). After Rabat: Middle East Risks and American Roles. Foreign Affairs, 53 (2), 284296

Vital, D. (1968). The Making of British Foreign Policy. London: George Allen \& Unwin

Wallace, W. (1977). The Foreign Policy Process in Britain. London: Allen and Unwin

Wilson, H (1979). Final Term: The Labour Government 1974-1976. London: Weidenfeld \& Nicolson. 
Wilson, H. ( March 7, 1974) A letter from Sir Harold Wilson to President Anwar Sadat, 7 March $1974-$ enclosed in a letter from Tom Bridges, No.10, Downing Street to A.A Acland, FCO 7 March 1974 (File FCO 93/554) The National Archive, London.

Wilson, H. (February $2^{\text {nd }}, 1975$ ) A transcript of the Prime Minister's interview with the ABC TV (File FCO 93/788) The National Archive, London.

Wilson, H. (January 30, 1975) Record of meeting, the Prime Minister and the Secretary of State for Foreign and Commonwealth Affair with a joint session of the Senate Foreign Relations Committee and the House Foreign Affairs Committee (File FCO 93/788) The National Archive, London.

Younger, K. (April 27, 1950) A statement by Mr. Kenneth Younger in his reply to a private notice question from Mr. de Chair (File FCO93/744) The National Archive, London.

Zbigniew, B. (1983). Power and Principle: Memoires of the National Security Adviser. New York: Farrar, Straus \& Giroux. 